\title{
SOME OBSERVATIONS ON THE EUROPEAN COURT OF JUSTICE'S POST-FRANCOVICH JURISPRUDENCE
}

\begin{abstract}
Vladimir Pavlović*
Summary: This article argues that the Francovich line of cases has revealed certain pro-integration leanings of the European Court of Justice. Following the Francovich judgment - considered reasonable by the vast majority of commentators - the Court has over time gone on to develop an expansive and sweeping doctrine of state liability to individuals with respect to the state's failure to implement directives - all this without much, if any, support in Community legislation. In developing this doctrine, the Court has overstepped its role as the interpreter of Community law and obscured the demarcation of powers and competencies between Member States and the European Union. The concrete implications of this development range from undermining the functionality and institutional structure of the European Union, to imposing high and unnecessary costs on Member States.
\end{abstract}

\section{Introduction}

This article has arisen out of a suspicion that the European Court of Justice has engaged, in its post-Francovich line of cases, in an unwarranted pro-European-integration agenda through an expansion of the principle that states are liable to individuals for damages suffered as a consequence of the state's non implementation of Community law. The suspicion has been confirmed in many areas, though not in all. The main thesis of the article is that the Court's pro-integration leaning is costly for the European Union because it erodes the Union's constitutional structure by creating a historical lacuna in its democratic legitimacy, and because it hampers its immediate wellbeing by imposing significant costs on Member States. This article proceeds as follows. Part II provides a historical background of the Court's decisions relevant to the thesis. Part III analyses the issue of the Court's relative compliance with the commonality principle of Article 288 of the Treaty. Part IV discusses certain concrete costs imposed on Member States by the Court's approach and the Community legislature's vague language. Part V discusses the seri-

\footnotetext{
* Associate, Allen \& Overy LLP, New York. JD University of Michigan Law School (2007). I am most grateful to Professor Walter van Gerven for encouraging me to embark me on this project.
} 
ousness of the breach requirement of the state liability doctrine. Part VI offers some additional general thoughts. Part VII concludes.

\section{Background}

The European Union has long struggled with the problem of compliance of Member States with its legislation. This has been true in particular for EU directives. Unlike EU regulations - legislation that is 'binding in its entirety and directly applicable in all Member States' - directives are legislation that Member governments are required to transpose into national law, binding as to the results to be achieved but leaving Member States a choice of methods to reach these goals. ${ }^{1}$ The Court of Justice has long had jurisdiction, under Articles 169 and 170 of the Rome Treaty, over cases of non-compliance of Member State governments with the EU legislation but, before 1992 and the ratification of the Maastricht Treaty, the EU treaties contained no provisions that allowed for the imposition of penalties on Member State governments for failure to implement EU directives. ${ }^{2}$ Needless to say, there have been many examples of governments abusing this circumstance.

Naturally, the Court has sought to enhance the compliance of Member States with EU directives. ${ }^{3}$ The first step in this direction was the Court's developing of the doctrine of 'direct effect', under which certain EU provisions have been interpreted as granting rights to individuals, in addition to imposing duties on governments. ${ }^{4}$ Under the 'direct effect' doctrine, individuals could enforce a right so granted against Member States in Member State court proceedings ${ }^{5}$ if the relevant right-granting provision was clear and unambiguous, unconditional, and not dependent on further action taken by the EU or national authorities. ${ }^{6}$ At the outset, the Court shrewdly realised that 'the vigilance of individuals concerned to protect their rights' can lift some burden from the Commission in securing compliance with the EU Treaty. ${ }^{7}$ Indeed, the doctrine of 'direct effect', together with the doctrine of supremacy of EC law over national

\footnotetext{
EC Treaty art 249.

2 In Maastricht, art 171was amended to allow for the imposition of penalties on governments that failed to comply with the Court's judgments. See G Garrett et al, 'The European Court of Justice, National Governments, and Legal Integration in the European Union' (1998) 52(1) International Organization 168 n 54.

3 Ibid

4 Case 26/62 Van Gend en Loos v Nederlande Administratie der Belastingen [1963] ECR 1.

5 JE Pfander, 'Member State Liability and Constitutional Change in the United States and Europe' (2003) 51 American Journal of Comparative Law 237.

6 Garrett (n 2) 169.

7 Van Gend en Loos (n 4).
} 
laws, ${ }^{8}$ provided a powerful enhancement to the enforcement of European law. ${ }^{9}$ But the Court did not stop there. Extending its original direct effect principle (in a quite straightforward manner), the Court held that 'direct effect' applied to regulations. ${ }^{10}$ Shortly afterwards, the Court decided that the doctrine also applied to directives, ${ }^{11}$ qualifying this principle in a later holding by ruling that 'direct effect' applies to a directive only when the deadline for its implementation has passed. ${ }^{12}$ Next, the Court ruled that private parties could not sue other private parties, but only the state, for breaching directives that have not been implemented in the national law, ${ }^{13}$ thereby endorsing the notion of vertical direct effect but rejecting the doctrine of horizontal direct effect. ${ }^{14}$ Temporarily pushing aside the 'direct effect' doctrine, the Court next held that, even if a directive has not been transposed into national law by the legislature, Member State courts must interpret existing national law in light of that directive, and that any ambiguous domestic legal rules must be interpreted, to the extent possible, in such a way as to achieve the results specified in the directive.$^{15}$ Finally, after the passage of the Single European Act in 1986 and the wave of directives that followed, the Commission intensified its efforts to sanction Member governments for the non-implementation or inadequate implementation of directives. However, the use of Articles 169 to 171 of the Rome Treaty was largely toothless due to the lack of enforcement provisions. Accordingly, governments would simply refuse to implement judgments and faced no consequences. ${ }^{16}$ Such was the case with Italy, which failed to implement a directive requiring it to set up a system ensuring that employees were paid salaries owed to them in the event that their employer went bankrupt. Even after the Commission brought a successful action against Italy under Article 169, the state audaciously refused to take action to transpose the directive. ${ }^{17}$ It was against this background that the Francovich ${ }^{18}$ ruling came about, marking the beginning of the second stage, much more potent than the previous one, of the Court-led enforcement of Community law.

\footnotetext{
8 Case 6/64 Costa $v$ ENEL 1964 ECR 585.

9 Pfander (n 5) 251-52.

10 Case 34/73 Variola Spa v Amminstrazione Italiana delle Finanza [1973] ECR 981.

11 Case 41/74 Van Duyn $v$ Home Office [1974] ECR 1337.

12 Case 148/78 Ratti [1979] ECR 1629.

13 Case 152/84 Marshall $v$ Southampton and South West Hampshire Area Health Authority (Teaching) [1986] ECR 723.

14 Pfander (n 5) 252.

15 See Case 106/89 Marleasing SA v La Comercial Inter De Alimentacion SA [1990] ECR I4135; see also Pfander (n 5) 252; Garrett (n 2) 169.

16 Garrett (n 2) 169. Note that the Maastricht Treaty had not been ratified at this time.

17 Case 22/87 Commission v Italy [1989] ECR-143.

18 Joined Cases C-6/90 and C-9-90 Francovich v Italian Republic [1991] ECR I-5357.
} 
In Francovich, two Italian workers sued the state for compensation of losses that they suffered as a result of Italy's failure to implement the directive. Ruling in favour of the workers, the Court held that liability was inherent in the system of the Treaty, and that it followed from the obligations of Member States under Article 5 of the Treaty to "nullify the unlawful consequences of a breach of Community law. ${ }^{19}$ The liability applies, according to the Court, even in the absence of comparable liability in national legal systems, provided that three conditions are satisfied. First, the directive must grant rights to individuals; second, the content of these rights must be identifiable; and third, there must be causation between the breach of the State's obligation and the damage suffered. ${ }^{20}$ The ruling in Francovich, however, also left much unresolved, particularly regarding the scope of liability. In several subsequent rulings, the Court refined the definition of Member State liability, recently in quite sweeping terms. ${ }^{21}$

In Brasserie/Factortame, ${ }^{22}$ the Court extended the Francovich principle, finding that it was applicable to breaches of Community law committed by Member State legislature, ${ }^{23}$ but also limited it by requiring that the breach be 'sufficiently serious. ${ }^{24}$ In addition, since Brasserie/Factortame involved alleged breaches of directly effective Community provisions enforceable in national courts (not an unimplemented directive, as in Francovich), the Court had to decide whether state liability applies in light of the existence and availability of alternative remedies. Although the Member States made an obvious argument that the availability of these alternative remedies made it unnecessary for the Court to declare an individual right to compensation from the state, the Court held that the right applies irrespective of alternative remedies. ${ }^{25}$ Crucially, the Court also hinted that state liability should lie in the case of violation of Community law by any branch of state government. ${ }^{26}$

The Court further refined Francovich, this time regarding directives, very shortly after Brasserie/Factortame, when it ruled in British Telecommunications that the conditions for imposing state liability set out in

\footnotetext{
19 Ibid paras 35-36.

20 Ibid para 40.

21 Pfander (n 5) 254.

22 Joined Cases C-46/93 and C-48/93 Brasserie du Pecheur SA v Germany [1996] ECR I1029 and $R v$ Secretary of State for Transport, ex parte Factortame Ltd [1996] ECR I-1029.

23 Both in cases of legislative omission in the case of Brasserie and legislative act in the case of Factortame. See W Van Gerven, 'Bridging the Unbridgeable: Community and National Tort Law after Francovich and Brasserie' (1996) 45 ICLQ 507, 517.

24 Brasserie/Factortame (n 22) para 51.

25 Ibid paras 18-20.

26 Ibid paras 32, 34 .
} 
Brasserie/Factortame apply to cases of the incorrect implementation of directives into national law. ${ }^{27}$ Similarly, in Dillenkofer, the Court ruled that a failure to take any measure to transpose a directive before the implementation deadline constituted per se a sufficiently serious violation of Community law and consequently gave rise to Francovich liability. ${ }^{28}$

Faithful to its allusion in Brasserie/Factortame that a state can be liable for breach by any branch of government, the Court decided the Köbler case, establishing a principle that a Member State may be liable for damages for an infringement of Community law by its court of last instance..$^{29}$ The Court also held that the serious breach requirement would be fulfilled where the decision [of a national court] concerned was made in a manifest breach of the case-law of the Court in the matter. ${ }^{30} \mathrm{~A}$ refinement of these principles came in Traghetti where the Court affirmed Köbler, holding that Member States are liable for damages caused to an individual by a manifest infringement of Community law attributable to a supreme court. ${ }^{31}$ Traghettis main innovation in this respect was the removal of the potential limitation of state liability - which could exist in national law - to cases of intentional fault and serious misconduct on the part of the court. Instead, if the Court thinks that a national court committed a manifest infringement of Community law (which may result from an interpretation of the provisions of law or an assessment of facts and evidence ${ }^{32}$ ), liability attaches to mistakes of national courts as well.

Viewed over time, this case law makes it apparent that the Court has gradually moved away from its original purpose - achieved through an intent-based Francovich doctrine - of preventing the abuse by Member States of a weak and unenforceable system of compliance with EU legislation. What has instead been established is a dramatically different, result-oriented, strict liability doctrine, one upshot of which is that, presently, a Member State's highest court's misinterpretation (as determined subsequently by the Court of Justice) of any provision of Community Law can render the state liable for damages for that misinterpretation.

\section{Commonality in Member States}

Article 288 spells out the commonality requirement, stating that 'the Community shall, in accordance with the general principles common to the

\footnotetext{
27 Case C-178/94 British Telecommunications [1996] ECR I-0000.

28 Case C-178/94 Dillenkofer $v$ Federal Republic of Germany [1996] ECR I-4845.

29 Case C-224/01 Köbler v Republic Österreich [2003] ECR I-10239.

30 Ibid para 56.

31 Case C-173/03 Traghetti del Mediterraneo SpA (in liquidation) v Italy [2006] All ER (EC) 983 para 46.

32 Ibid.
} 
laws of the Member States, make good any damage... ${ }^{33}$ Of course, nobody would seriously maintain that a common principle is one that necessarily exists in all Member States. To satisfy this requirement of commonality, it is enough that the principle be accepted by the majority in a sufficiently large number of Member States in which the issue has arisen in similar circumstances. ${ }^{34}$ The principle need not even be expressed as a concrete rule and may reflect a guideline or a maxim, so long as it results in similar solutions in similar situations. ${ }^{35}$

While it is quite uncontroversial that the commonality requirement has been satisfied in Francovich, doubts have been raised as to whether it has been met in Brasserie/Factortame and Köbler, ${ }^{36}$ and it is even more doubtful that it has been met in Traghetti. Specifically, the principle that Francovich liability applies when a violation of Community law is attributable to a Member State legislator has no support whatsoever in the laws of the Member States. ${ }^{37}$ Probably recognising this, the Court of Justice in Brasserie/Factortame offered in support of its position a rule of international law that a state must be viewed as a single entity regardless of which branch of government is responsible for the breach. ${ }^{38}$ While this principle, in the abstract, gives some support to the Court's decision, it is not clear how it fulfils the commonality requirement.

Similarly, in Köbler, the Court ruled, deferring to the opinion of Advocate General Leger, that liability for court decisions is accepted in nearly all the national legal systems of the Member States. ${ }^{39}$ The reasoning of the Advocate General, however, merits at least two observations.

First, the Advocate General partially bases his claim, that the commonality requirement is satisfied, upon the recognition by the EU members within the Council of Europe of state liability for violations of human rights under the European Convention of Human Rights (ECHR). ${ }^{40}$ This comparison is unconvincing, for at least two reasons. First, the cases under ECHR concern very important, fundamental rights, while in the case of Köbler liability, the courts might be dealing with something as trivial

33 EC Treaty art 288 (2) (emphasis added).

${ }^{34}$ W Van Gerven, 'Bringing (Private) Laws Closer to Each Other at the European Level' in F Cafaggi (ed), The Institutional Framework of European Private Law (Oxford University Press, Oxford 2006) 75.

35 Ibid.

36 Ibid.

37 Ibid (citing Van Gerven et al (eds), Cases, Materials and Text on National, Supranational, and International Tort Law (2nd edn Hart Publishing, Oxford 2000)).

38 Brasserie/Factortame (n 22) paras 32, 34.

39 Köbler (n 29) para 48; see also Classen's comment on Köbler (2004) 41 CMLR 813, 815.

40 Köbler v Austria, Opinion of Advocate General Leger, 8 April 2003 paras 79-80. 
as a Community directive on the luminosity of bicycle taillights. ${ }^{41}$ Second, in the ECHR, Member States have expressly submitted themselves to the jurisdiction of a special international Court and to the possibility of individual complaints and the potentially ensuing state liability for individual damages resulting from the mistakes of their high courts. ${ }^{42}$ This point is of particular importance in this article because it elucidates the fact that, unlike the European Court of Human Rights that adjudicates cases under the ECHR and is endowed with full democratic legitimacy by the assent of Members of the Council of Europe, the Court of Justice, at least in the case of Köbler liability, lacks such legitimacy.

The second point worth illuminating in the Leger opinion is that the Advocate General himself reveals inconsistency in the application of the legal principle of state liability in many Member States. Namely, he asserts from the outset that the principle of state liability for judicial acts is common across all Member States, only to proceed to list no less than eight exceptions for Member States that do not accept the principle in some form. While it is possible that he is correct in his conclusion that in spite of the divergences which exist today, the principle of State liability - for a judgment of a supreme court in breach of a legal rule - is generally acknowledged by the Member States, or at least a strong tendency in that direction can be detected,' it is at least contestable, since the Advocate General never defines the criteria used to decide what makes a principle common. Furthermore, after reading the data laid out in support of the purported common agreement across different Member States ${ }^{43}$ of holding a state liable for the acts of its courts, it seems that a conclusion that the principle is not common enough to satisfy the requirement of Article 288 would be just as valid. ${ }^{44}$

\section{Consequences of the ambiguity of language of the Court of Justice and Community legislation}

Much of Community legislation, as well as many decisions of the Court of Justice, suffers from less-than-clear language. ${ }^{45}$ A survey of the Court of Justice's case law would reveal the Court's reluctance to revise overtly its earlier judgments, amplifying the lack of clarity. For example, in Dillenkofer, the Court holds that 'failure [of states] to take any measure

\footnotetext{
41 PJ Wattel, ‘Köbler, CILFIT and Welthgrove: We Can’t Go On Meeting Like This' (2004) 41 CMLR 177, 187.

42 Ibid.

43 Leger Opinion (n 40) paras 77-82.

44 J Komarek, 'Inter-Court Constitutional Dialogue after the Enlargement - Implications of the Case of Professor Köbler' (2005) 1 Croatian Yearbook of European Law and Policy 75.

45 Wattel (n 41) 178-79, citing Regulation $1408 / 71$ on the social security of migrant workers as an example of unintelligible legislation.
} 
to transpose a directive in order to achieve the result it prescribes within the period laid down for that purpose constitutes per se a serious breach of Community law', and gives rise to Francovich liability. ${ }^{46}$ Plain reading of this language implies that a Member State might avoid the imposition of Francovich liability if it takes at least some measures directed towards transposing the directive on time. The phrase has, however, been interpreted much more broadly. Namely, commentators have asserted that a '[f]ailure to implement a directive on time, or at all, is per se a sufficiently serious breach to give rise to the Francovich liability. ${ }^{37}$ The obvious discrepancy in the possible readings of the provision could put Member States in quite a predicament when deciding how to go about implementing a directive. As mentioned before, a Member State for which it is complicated or expensive to implement a directive in a timely manner might plausibly read the Court's language as allowing it to take some measures towards the implementation and so avoid liability for damages, even if the full implementation may exceed the deadline. The language ambiguity, of course, should not be permitted to serve as an excuse for states to avoid implementing a directive, but it is clear that in the process of the making of a decision on how to go about such an often very costly enterprise it might, among other reasons, cause a delay.

Another example of the insufficient clarity in the Court's case law has to do with the question of causation. In Brasserie/Factortame, the Court alluded to the possibility that an individual contribution to the occurrence of damage might break the chain of causation. ${ }^{48}$ This approach to causation is not reflected in the laws of all Member States; specifically, in English law it is a matter of the measure of compensation, not causation. ${ }^{49}$ In light of the already existing different approaches to the issue, potentially varied interpretations of this language by national courts could have a significant effect on the Francovich remedy in national courts. ${ }^{50}$

These examples, showing that ambiguously worded legislation will probably be differently interpreted in different Member States, are a good introduction to a discussion on the important circumstances that the Court must carefully consider whenever it writes its opinions, namely, the three markedly different legal cultures in Europe. ${ }^{51}$

\footnotetext{
46 Dillenkofer (n 28) para 29 (emphasis added).

47 TK Hervey, 'Francovich Liability Simplified' (1997) 26 ILJ 74, 77 (emphasis in original).

48 F Smith and L Woods, 'Causation in Francovich: The Neglected Problem' 1997) 46 ICLO 925, 928 (citing Brasserie/Factortame para 79).

49 Ibid; see also Van Gerven (n 23) 523-24.

50 Smith and Woods (n 48) 928.

51 Van Gerven (n 34) 40.
} 
It is obvious that, in an entity with such a diversity of rich legal traditions and languages that Europe is, it is exceedingly challenging to write complex texts in such a manner as to ensure even a similar perception and understanding by all its peoples (not to mention the potential issues that arise with translation, which only amplify the problem ${ }^{52}$ ). So much has already been conceded by the Court. ${ }^{53}$ Commentators have observed three main groups of legal traditions in Europe: English, French, and German, cleverly dubbed judges, legislators, and professors. ${ }^{54}$ Specifically relating to court opinions, English judgments reflect the language of a judge sitting on the bench, the French versions are curt and authoritative, resembling legislative language, while the German ones purport to reach their conclusions only after a high-level academic debate on the issue. ${ }^{55}$ These three approaches to law reflect deep differences in legal systems, represented by case-oriented English common law, rule-oriented French civil law, and concept-oriented German civil law, which are very much alive today in Europe and which obviously play an important role in the game of the articulation and understanding of legal rules, whether legislative or judge-made. ${ }^{56}$ One might contend that the existence of such diversity in legal mentality and tradition validates the often ambiguous language of the Court of Justice and Community legislation. Indeed, it is not difficult to argue that such diversity in approaches invites a certain level of generality in expression so that a common understanding can be achieved over time. This proposition has merit and is well taken here. Nevertheless, the vagueness necessarily present in any language that aims to be wide-ranging raises a host of issues and, in the present context, calls for a balancing of the merits and the drawbacks of the current degree of extension of Francovich liability.

Given the existence of potential problems of interpretation arising from the ambiguity of language, several questions emerge. First, it clearly seems equally likely that the ambiguity will cause as many mistakes to be committed by the Community institutions as by the national ones. In theory, this should not be problematic since Article 288 unequivocally establishes the principle of liability of Community institutions, ${ }^{57}$ which is confirmed in Brasserie/Factortame in equally explicit terms, adding that, in similar circumstances and in absence of a particular justification, the

\footnotetext{
52 Wattel (n 41) 178-79.

53 See, eg, Brasserie/Factortame (n 22) para 76 ('the concept of fault does not have the same content in the various legal systems').

54 RC Van Caenegem, Judges, Legislators and Professors: Chapters in European Legal History (Cambridge University Press, Cambridge 1987).

55 Van Gerven (n 34) 41.

56 Ibid.

57 Art 288 (n 33).
} 
liability of states is equal to the liability of the Community. ${ }^{58}$ Applying this principle practically in the context of Köbler liability yields the conclusion that liability attaches to the Community for the judgments of the Court of Justice that manifestly violate Community law; for example, overstepping competence limitations. ${ }^{59}$ At least one author maintains that manifest errors by the Court are not rare, ${ }^{60}$ but there is not yet a mechanism available for a review of the Court's decisions. Applying Köbler, then, manifest errors in judgment by the Court of Justice should impose liability on the Community, and the failure of European legislature to create a mechanism for reviewing the Court's decisions for manifest infringements should give rise to Brasserie-like liability for legislative omission.

Be that as it may, no justification has been offered for what seems to be the inconsistent practice of the Court of holding the Member States liable, but not holding the Community institutions equally liable. The harshness of the inconsistency is underscored by the fact that, unlike the liability of states - which is absent from any legislative text - the liability of the Community is supported by the plain words of Article 288.

It follows that subjecting Member States or the Community to liability for good faith mistakes of their judicial or legislative institutions, especially considering the issue of ambiguity of language and the resultant unclear guidance, is unwise and unjustified because it lacks democratic legitimacy. The damages paid by the Member States in such cases are, of course, always ultimately paid by the citizens' taxes. ${ }^{61}$ This fact might not be obvious to many taxpayers, as the economic strain from this liability on an average citizen is negligibly small. Of course, as practically convenient a strategy as the spreading of loss might be, it can never alone be a principled justification for the imposition of liability on Member States. Citizens of all Member States routinely express their political will regarding the economic consequences of the acts of their governments, irrespective of how small these consequences might be.

Ambiguity of language necessarily creates inefficiencies (which are only aggravated by the Court's reluctance to overturn its prior judgments). This is acutely obvious in the case of Köbler liability, the legacy of which is likely to create more preliminary referrals and more costly procedure. ${ }^{22}$ These inefficiencies are, likewise, paid by the taxpayers who

\footnotetext{
58 Brasserie/Factortame (n 22) para 42.

59 Wattel (n 41) 184.

60 Ibid (citing the Schumacker, Gilly, Gschwind, De Groot cases as examples where the Court 'manifestly infringed the free movement of workers and the limitations of its competence').

61 Ibid 186.

62 Ibid 181.
} 
never authorised the Court's expansive mode. ${ }^{63}$ But more importantly, to the extent that one of the obvious purposes of the imposition of liability is compliance by national institutions with Community law - as evidenced by the Brasserie/Factortame and Köbler decisions ${ }^{64}$ - the effort is futile for at least two reasons. First, a trained and competent public servant can do nothing more than perform his or her job in good faith. To the extent that some mistakes are made in this process, it is not clear how a punishment can improve it and bring about a more 'correct' interpretation of Community law. Second, at least if the equal ability of these government employees is presumed, then, statistically, a well-meaning employee (whether it be a legislator or a judge) will make as many good-faith mistakes as any other. In the context of Köbler liability, national judges will statistically err by the same percentage as the judges of the Court of Justice (to be sure, the Court of Justice has the final say on the interpretation of Community Law, but it is impossible for the national courts to know such interpretation a priori). Thus, from the point of view of deterring mistakes by the institutions (or rectifying the institutions), the imposition of financial penalties would not seem to do the job.

In summary, a balancing of the merits and the drawbacks of the Court of Justice's expansion of Francovich liability draws the conclusion that, in light of the serious and complex concerns that arise as a consequence of the ambiguous language of Community institutions, including both the legislature and the Court itself, the Court's unrestrained judicial philosophy of imposing liability for damages on well-meaning states is unwarranted.

\section{Seriousness of Breach}

One might take some comfort in the fact that there is a check on the Court's discretion in expanding Francovich liability: the requirement of a sufficiently serious breach of Community law must be fulfilled in order for liability to be incurred. The principle originates in the famous Schöppenstedt decision that states that individuals can obtain damages for Community legislative action of a general nature only if there is a sufficiently serious breach of a superior rule of law. ${ }^{65}$ In later decisions, most notably in Brasserie/Factortame, the Schöppenstedt principle has been restricted to mean that the Court need not assess the seriousness

\footnotetext{
63 Ibid 186.

64 Imposing state liability for breaches of the Community law by the legislature and judiciary, respectively, of a relevant Member State.

65 Case 5/71 Zuckerfabrick Schöppenstedt v Council [1971] ECR 975; see also C Hilson, 'Liability of Member States in Damages: The Place of Discretion' (1997) 46 ICLQ 941; see W Van Gerven, The European Union: A Polity of States and Peoples (Stanford University Press, Stanford 2005) 113.
} 
of the breach if the Member State in question had narrow discretion in its actions. ${ }^{66}$ An extension of this principle implies a sliding scale where, the wider the discretion the states have over the implementation of the Community law, the more serious the breach must be for there to be liability. In Dillenkofer, however, the Court restricted this principle further, holding that a failure by a state to implement a directive within the time period given to it by the Community is per se a sufficiently serious breach of Community law. ${ }^{67}$ In Köbler, the Court set out some criteria for determining whether a breach was sufficiently serious, ${ }^{68}$ and asserted that a 'manifest breach' of Community law will always be sufficiently serious. In Traghetti, the Court just extended the Köbler principle to apply to inadvertent mistakes as well.

Discussing the issue of the seriousness of breach in great depth is beyond the scope of this article. Still, two observations are relevant. First, several authors have convincingly argued that the case law of the Court of Justice that attempts to clarify how the serious breach test fits in with the existing Francovich conditions has produced much confusion, due to the Court's unpredictable treatment of the concept. ${ }^{69}$ The second point is that, in light of this unpredictable treatment, Member States have a very practical, if futile, choice. They can choose to act and therefore attempt to predict the Court's approach to the serious breach test. In that case, they will likely err on the side of caution and lean towards interpreting any potential infringement as sufficiently serious for Francovich liability to apply. This is undesirable because it is done for fear of sanctions and not out of a sense of democratic obligation to interpret laws faithfully, as well as because it causes overly cautious behaviour by the states. Member States can also choose to refer more questions under Article 234, and let the Court make the decision, which is plainly burdensome from the standpoint of judicial economy.

Further, while the seriousness of the breach test is seemingly a guardian of the powers of Member States in the Court's post-Francovich jurisprudence, sound arguments have been advanced that it has been applied inconsistently and that it is doctrinally non-refined..$^{70}$ A Eurosceptic might hence say that such circumstances render it merely a placeholder for any, however unprincipled, arguments the Court might choose to use in support of the substantive outcomes it wishes to reach.

66 Brasserie/Factortame (n 22) para 25.

67 Dillenkofer (n 28). Note that this is at least the prevalent interpretation of the judgment in Dillenkofer. I pointed above that there might be other interpretations.

68 According to some commentators, the Court had misapplied its own criteria in the very Köbler case. See, eg, Komarek (n 44) 85.

69 See Hilson (n 65) 942.

70 Ibid. 
But even a more neutral observer is likely to admit that the consequences of such a treatment are undesirable because they undermine the institutional structure of the European Union and inflict unnecessary and high costs on all parties concerned.

The claim advanced in Part IV of this article - that due to ambiguous language and translation problems liability can arise even for the good faith mistakes of national institutions - might appear undercut by the requirement of the sufficiently serious breach. In other words, one could contend that the Court would be hard pressed to find a sufficiently serious breach that warrants liability in cases where a Member State or its institution makes a good faith mistake in interpretation of a directive. But the protection intended to be afforded by the requirement of the seriousness of breach does not address the scenario of vastly varying interpretations of Community law provisions. Unless one believes that (notwithstanding divergent approaches to interpretation in Member States as well as translation issues - all of which have a potential to spread a shroud of fog over the 'correct' meaning of a directive) good faith attempts to interpretation by the courts of Member States must somehow be close to that of the Court of Justice, ${ }^{71}$ it should be admitted that the sufficiency of the breach requirement does little, if anything, to protect benevolent Member States from committing an offence that could result in liability. ${ }^{72}$

\section{Some Additional Observations}

Despite the trend engineered by the Court of Justice toward expanding powers of the Community through what might be viewed as unwarranted judicial activism, one could powerfully argue that, in spite of the absence of express legislation, Member States are in assent with the Court's rulings, since they respect its judgments. This is exemplified by

\footnotetext{
${ }_{71}$ This author is unaware of any such arguments having been made in the legal literature.

72 Admittedly, there are cases in which the Court of Justice appears to have characterised the breach by a Member State as not sufficiently serious in order to avoid imposing state liability if that Member State has done something in the general direction of implementing the relevant Directive. See Case C-319/96 Brinkmann Tabakfabriken GmbH v Skatteministeriet [1998] ECR I-05225. This author is unconvinced that occasional examples of such an application of the sufficiently serious breach requirement change the position advanced in this article. Although the Court's approach in Brinkmann could be viewed as generally lenient, the Court never stated that good faith mistakes (even if the Court itself, by the nature of things, has the right to such categorisation) by state institutions are less likely than the bad-faith ones to produce breaches that are sufficiently serious for the purposes of the imposition of liability on states. Furthermore, the Brinkmann case did not deal with a mistake in interpretation but, rather, with the inability of implementing a directive; hence, it should be seen as an indication of the Court's tendency to forgive the non-implementation of a directive to those States that have taken at least some steps towards it, rather than a sign of lenience towards the States that have simply misunderstood one (even in good faith).
} 
Germany's and France's acceptance of the Court's earlier decisions and by the UK's deference more recently in (an earlier) Factortame case, where Lord Bridge rejected public calls warning that the Court's decision violated a long-standing British tradition of unrestrained power of Parliament, and asserted the supremacy of Community law. ${ }^{73}$ National legislatures, likewise, have done nothing to counter the Court of Justice's judgments. To be sure, there have been cases in the past where the Member State governments have deemed the Court's decisions unacceptable and reacted by amending the Treaty. ${ }^{74}$ The unwillingness of Member States to react similarly to the post-Francovich sequence of cases might then be understood to reflect the agreement of states with the decisions, which would provide some relief to the worrisome appearance of the lack of democratic legitimacy. In the same vein, there are provisions in the Treaty which expressly prohibit the Community legislature from harmonising national laws in certain areas. ${ }^{75}$ Some of these areas are: education, vocational training, culture, and public health. ${ }^{76}$ Obviously, one can argue that if Member States wanted to retain certain competencies, not only could they do this by amending the Treaty, but they could have done so when they ratified it, as they did with these areas.

Despite the foregoing, however, the suggestion is questionable that the Member States have approved of the Court's post-Francovich jurisprudence by their legislative inaction and executive compliance. First, the course taken by the Court of Justice was not obvious at the time when the Treaty was signed. If no textual support exists in the legislative texts for the Court's subsequent jurisprudence on this issue, it is difficult to imagine how the Member States could have prevented the current judicial treatment by drafting some of the provisions differently. Second, amending the Treaty has become increasingly difficult, in light of the accession of new Member States into the Union (mirroring in this sense the difficulties in amending the US Constitution). Any attempt to amend the treaty is likely to be subject to the possibly tense relations between the legislatures of the Member States and the Community, which would make it difficult to agree on any consequential amendments. Even in the case that the Treaty is successfully amended, the Court might not be immune to influences by certain powerful members. For example,

\footnotetext{
73 See Lord Bridge's opinion in Regina $v$ Secretary of State ex parte Factortame Ltd [1991] 1 All ER 70, 107-08 (HL).

74 See, eg, Case 262/88 Barber $v$ Guardian Royal Exchange [1990] ECR I-1889. After the decision, the governments added a protocol to the Maastricht Treaty that limited the scope of the Court's judgment; see also Garrett (n 2) 166.

75 Van Gerven (n 34) 60.

76 EC Treaty arts 149(4), 150(4), 151(4), and 152(4), respectively; see Van Gerven (n 34) 60.
} 
one commentator suggested that the Court of Justice might be willing to tailor its approach toward state liability in ways desired by the core Member governments, especially France and Germany. ${ }^{77}$ Hence, the argument that the assent of Member States to the Court's judgments serves as a validation to the Court's jurisprudence does not seem to be as strong as it might appear.

\section{Conclusion}

This article has ventured to show that the European Court of Justice's sequence of decisions expanding state liability is coloured with a pro-integration agenda. This is undesirable both because such an approach lacks democratic legitimacy and because it imposes serious costs on Member States. Lack of democratic legitimacy is reflected in the absence of any textual support in the EC Treaty for the Court's approach, as well as in the fact that especially the Court's latest decisions do not satisfy the commonality requirement laid out in Article 288 of the Treaty. Equally importantly, the ambiguity in expression both by the Court and the European legislature continues to inflict significant costs on Member States, and the Court's insistence on expanding the Community powers is magnifying these costs further. The requirement of sufficiently serious breach, although protective of the states at first glance, does little to alleviate these concerns. If the Court had its eye on a long-term picture of Europe as a balanced and sustainable constitutional entity, it would be well advised to take a more cautious and restrained role.

77 Garrett (n 2) 173. 